\title{
THE REGIONAL TRANSNATIONALIZATION OF LATIN AMERICAN NURSING
}

As a knowledge generator, the university has always worked towards the internationalization of its research function, based on the researchers' autonomy. As from the 1990's, as a consequence of the globalization process, this assertion is no longer restricted to the research function, but also includes the teaching function ${ }^{(1)}$.

Nowadays, the university should work to produce pluriversity knowledge, that is, contextual knowledge to the extent that the principle organizing its production is its possible application. As the knowledge is applied beyond the university walls, the initiative to formulate the problems one intends to solve and to determine criteria for their relevance is the result of sharing between researchers and users. In pluriversity knowledge production, unilaterality is replaced by interactivity, which has gained enormous power by the revolution in information and communication technologies ${ }^{(2)}$.

Technological development is considered one of the most important tools for internationalization and for the use of the web to strengthen distance education and build collaborative research networks.

As a result of globalization, the university increasingly needs to find regional synergies and intensify networks so as to stimulate and expand existing forms of transnational cooperation and multiply them in the framework of bilateral or multilateral agreements, in line with principles of mutual benefit ${ }^{(2)}$.

In this sense, Latin American Nursing has made efforts to transnationalize teaching and research institutions and establish regional collaborative networks. Initiatives in this sense include welcoming foreign students, mainly in graduate programs; international associations involving consulting services to foreign universities; collaborative research projects, distance education, virtual learning, faculty mobility, on-line libraries, research funding for students and faculty, among others.

Some regional actions are just beginning, such as student exchange at undergraduate level and curriculum adaptations, while others are flourishing, such as the Collaborative Networks coordinated by the Pan American Health Organization/World Health Organization (nursing in patient safety, mental health nursing, child health nursing, nursing researchers and HIV, care management, nurse migration, nurses in elderly health, nursing journal editors etc.); the offering of distance education, such as the courses offered to health professionals from Latin American countries with a view to skills development in drugs abuse control ${ }^{(3)}$ and the Electronic journal portal in the Virtual Health Library-Nursing, currently joining 18 Nursing journals published in Brazil, Colombia, Chile and Spain.

Thus, transnational research centers need to be created, addressing themes and problems of specific interest to this region, and the dissemination of their research results needs to expand. In this context, the Latin American Journal of Nursing invites researchers from Argentina, Belize, Bolivia, Brazil, Chile, Colombia, Costa Rica, Cuba, Ecuador, El Salvador, Guatemala, Haiti, Honduras, Mexico, Nicaragua, Panama, Paraguay, Peru, Dominican Republic, Uruguay and Venezuela to submit manuscripts about regional problems, with a view to encouraging new regional partnerships and contributing to the transnationalization of Nursing knowledge dissemination in Latin American nursing.

${ }^{1}$ Editor of Latin American Journal of Nursing, Full Professor, University of Sao Paulo at Ribeirao Preto College of Nursing, WHO Collaborating Centre for Nursing Research Development, Ribeirao Preto, SP, Brazil, e-mail: marziale@eerp.usp.br. 


\section{REFERENCES}

1. Michelotto RM. Dossiê: Política de educação superior no Brasil no contexto da reforma universitária. Educ Rev jul/dez 2006;(28):13-5. doi: 10.1590/S0104-40602006000200002.

2. Santos BS de. A universidade no século XXI: para uma reforma democrática e emancipatória da universidade. 2004. [acesso em: 15 jan 2009]. Disponível em: http://www.mec.gov.br/reforma/Documentos/PALESTRAS/2004.7.20.12.10.23.pdf

3. Mendes IAC, Marziale MHP. Developing competencies for drug demand reduction. Rev Latino-am Enfermagem 2008;16, n. spe:505-6. doi: 10.1590/S0104-11692008000700001. 